\title{
A Review of the Features of Safavid Documents
}

\author{
Mozhgan Esmaili ${ }^{1}$ \\ ${ }^{1}$ Research Center of Iran Cultural Heritage Organization, Tehran, Iran \\ Correspondence: Mozhgan Esmaili, Research Center of Iran Cultural Heritage Organization, Tehran, Iran. \\ E-mail: Esmailimozhgan20@gmail.com
}

Received: January 21, 2016 Accepted: February 16, 2016 Online Published: March 31, 2016

doi:10.5539/jpl.v9n2p56

URL: http://dx.doi.org/10.5539/jpl.v9n2p56

\begin{abstract}
During the rule of the Safavid dynasty (1502-1722 AD) the chancellery and royal documents played an important role in the administration of the state affairs.

The royal documents constituted one of the main components of the chancelleries in management of the day-to-day affairs.

The said documents are one of the main sources of research which include all royal communications, decrees, documents, political agreements, administrative and officials writings, economic, cultural and military reports, judicial, financial and legal documents as well as private and family communications.

Hence a study of the royal documents would shed light on the mode of administration during the said era. The present paper is an attempt to review the main features of some of the documents circulated in the chancelleries and throughout the state during the Safavid era. The Safavid documents can be divided into various categories on the basis of their functionalities. The main thrust of the present paper is to discuss the nature of the diwanyat as well as their functions in the administration of the state where there was no constitution and the royal decrees and other forms of royal documents effectively played the role of the constitution and law. Attempts have been made to rely on the original documents, which are available in different archives, libraries and museums.
\end{abstract}

Keywords: Safavid, chancellery, administration, Order, royal decree, draft, Insignia, religious Order, confirmation, Text

\section{Introduction}

With the advent of the Safavid dynasty (1502-1722 AD) in the Iranian political landscape the chancellery practices played an important role in the administration of the affairs of the country.

The royal documents constituted one of the main components of the chancelleries in the management of the state affairs. The said documents are one of the main sources of research which include all royal communications, decrees, documents, political agreements, administrative and officials writings, economic, cultural and military reports, judicial, financial and legal documents as well as private and family communications.

In fact during the Safavid era a copy of all documents and letters was recorded in the "dafaater khulud" (a kind of archives), which were kept by a secretary at the store of the secretariat of the high court (daftar khaneh divan a'la).

During this period all the documents were categorized and kept on the basis of subject, region and date and features and list of each category were recorded in a separate book called "sarreshteh". Hence a study of the royal documents would shed light on the mode of administration during the said era. The present paper is an attempt to review the main features of some of the documents circulated in the chancelleries and throughout the state during the Safavid era.

The Safavid documents can be divided into various categories on the basis of their functionalities. Broadly speaking, the Safavid documents can be divided into diwanyat (official letters), sultanyat (royal letters), ikhwanyat (family letters) and sijelat (deeds and documents).

Diwanyat are the historical letters which were prepared about state and administrative affairs at the government offices. Sultanyat which included the kings' and princes' letter and sometimes official letters.

Ikhwanyat included the family letters and friendly letters. Sijelat included the deeds and documents about the 
day-to-day affairs referring to the daily legal and economic transactions.

The main thrust of the present paper is to discuss the nature of the diwanyat as well as their functions in the administration of the state where there was no constitution and the royal decrees (farmans) and other forms of royal documents in effect played the role of the constitution and law. Attempts have been made to rely on the original documents, which are available in different archives, libraries and museum. However, since with the passage of time some of these documents have been lost and only their copies (sawads) are available, their copies have been analyzed in the present paper. The copies have been procured from what was called munshat (some sort of dossier or collection of letters) during the Safavids.

Since diwaniyat are the subject of our study, our study focuses on the latter category and the chancellery practices, which are related with it. Study of a large number of documents brings out different varieties of the official Orders or the asnad-i diwani. Some contemporary and non-contemporary manuals and munshat give us information about the various types and forms of these Orders out they are not comprehensive enough as to give as a full idea on how and what distinction one should make between these documents. Therefore one should see the documents himself to get an idea by studying them and by comparing them with each other, in Order to be able to distinguish them. It should be mentioned that sawad of faramin used to be included in a collection of munshat, from our point of view, this is very important since it gives us an idea of the structure of the real documents. With the help of these manuals, we can make out whether a particular documents is genuine or not and similarly in a mutilated document, we can reconstruct the missing portions. The nature of such Order was different as it was issued for specific purposes, such as appointment, employment, grants, permission, punishment, exemption of taxes, treaties etc. Therefore it is quite likely that it does confirm to the standard norm laid down in any manual.

The diwanyat, which is the main focus of the present paper, include various kinds of documents which are discussed below.

\section{Royal Decree}

The Persian word farman literary means royal decree, Order or commandment (fig.1). The word was in vogue even before the Safavid era, but was widely used during the period under study.

Dehkhuda defined a farman as an Order and command but the term of farman has been used invariably for every written royal Order. (Dehkhuda, 1952:190) Royal Orders for the performance of certain obligations to the chiefs and subordinate rulers and to the hukam-i-iyalat (chiefs of the provinces) were issued in the form of farman.

The farmans were divided into six groups, that is, appointment decrees, grant decrees, passports, contracts, decrees stemming from the king's legal activities, and decree for the announcement of the decree. (Busse, 1988:42)

Text of the Order was read by the grand minister (vizier) before the king. The king then Ordered for making a copy of it on a long paper of 2-1/2 feet long and 13 or 14 inches wide, it was written only in black ink while the places where they mentioned God's name was written in abtala (golden ink) and the name of the Prophet and Imams was written in azure while the name of the king was written in red ink. Only in case the holy names were not mentioned, the name of the king was written in golden ink. (Chardin, 1957:220)

\section{Order}

Order or Hukm literarily means an Order, judgement, decree, rule and regulation, some of the hukm like hukm-i-bayazi needed only the king's or his umara's seal and signature and these documents need not necessarily pass through the dafater so as to avoid delay, and also to keep the contents a secret (fig.2). Such documents were more creditable than the hukm-i-daftari.

In Safavid period, hukm were usually issued by diwan begi who was an important commander who sat in kishikhaneh along with the sudur, and calling to account the sinners, (Mirza Samia, 1987: 12) or issued from ghazi Shar'a in Order to carry out the punishments. (Ibid: 3 )

It seems hukm as compared to the other Orders and documents was less important, as the salary of diwan-i-ahkam was even less than the dawatdar-i-argham. Usually these hukm were issued for criminal cases and bear the tughra-i-hukm-i-jahan-mauta'a shud. (Minorsky, 1955:270) Financial affairs were another subject for which hukm were issued, as ahkam-i-mulazemat, mawajeb, tuyul, hamesaleh and ina'm. (Mirza Samia: 1987: 7,36 ) According to Busse, such ahkam could be issued for an Order of appointment for land grants relating to the contracts, and for issuing the passport which were supposed to be the legal activites of the sultan. (Busse, 1988:40, 43) Moreover, tughra-i-humayun shud in ahkam-i-tankhah, grant of tuyul, suyurghal, hamesaleh all the 
Orders related to the army were issued in the form of hukm. (Papaziyan, 1968:20, 28)

Although Maghami mentions that hukms generally do not carry tughra, at the end, phrases such as mustufiyan' azam diwan' ala rughe in dastkhat ra dar dafater khulud thabt namayand, are written. (Ghaem Maghami, 1970:68)

Infact, of the surviving documents show that the tughra was very much there on the hukm and the formula was hukm-i-jahan muta'a shud with invocation of huwa. (Anonymous Mss: 6293)

While Mirza Sami'a says that," the tughra of hukm-i-jahan muta'a shud is always in the ahkam which were issued by diwan begi, and munshi-ul-mamalek drew the tughra with golden and red ink." (Mirza Sami‘a, 1987: 24)

It seems the usage of golden ink and keeping of the margins were the practices which the Safavid followed from the Mongol rulers, and words like allah ta'la, be jawar-i-rahmat-i-hagh, shah-i-babam anarallah burhanahu and other words which were written in margin were always written in golden ink. (Busse, 1988:73)

Chardin writes hukmnevis used to write only those Orders which were to be sealed by small seals. (Chardin, 1970:45) While Mirza Rafi'a says that, " two kinds of ahkam were issued: I. akham-i-bayazi which were issued by diwan begi with tughra of hukmi-jahan muta'a shud and II. ahkam-i-iltezami which were issued on the basis of taligheh-i-diwan begi by munshi-i-diwan." (Mirza Rafi'a, 1969:544)

These Orders were issued to redress the grievances of the people generally on their complaints. (Ibid: 550) Therefore, we can say that during the Safavid period most of the ahkam were related to canonical and judicial Orders.

\section{Confirmation}

Confirmation or Ta'ligheh literary means a description or correction on a written thing on its margins or any endorsement by the high officials like wazir or wakil.Ta'ligheh belonged to the category of diwaniyat documents (fig.3).

Ta'ligheh was considered as a sign of confirmation and this conformation was done by the grand wazir. (Mirza Rafi'a, 1968:92) Depending upon the nature of the document, different kinds of Ta'ligheh were issued which were like a kind of permission. For instance, in case of judicial matters, Ta'ligheh was the Order for ihzarnameh (summons) which diwan begi used to send for the persons to be called and the summons which had been issued were called Ta'ligheh and these summons which sent out of the area was called Ta'ligheh iltezami. (Mirza Sami'a, 1987: 12, 13)

There were some the Ta'ligheh which were related to the financial affairs and in fact that transaction of taxation and treasury matters were not honoured without ta'ligheh of the grahd wazir (Ibid:5) and unless and ta'ligheh is affixed with the seal of wazir the king's seal will not be affixed. (Ibid: 15)

For the welfare of the people (ru'aya) the scribes of daftar Khaneh-i-diwan 'ala wa khaseh-i sharifeh issued ta'ligheh wazir' azam which were also known as ta'ligheh-i-takhfif for reducing the burden of taxes. (Ibid: 6)

These measures were taken at the hours of crisis due to bad weather conditions, unexpected events and destruction of the crops. These Orders were issued to exempt the people from paying the taxes.

Ta'ligheh-i-mawajeb or Order for the payment of salary was another kind of Order which was issued by the grand wazir. (Ibid: 14). Still another type of ta'ligheh was khedmat wa mulazemat which could not be issued without the grand wazir's ta'ligheh and the other had to affixed with the seal of mehr-i-athar and register it in the dafater. Even if the Order was conveyed orally ta'ligheh of the grand wazir was necessary. (Mirza Rafi'a, 1968:42).

It should be mentioned that all ta'lighjat-i-manaseb were to pass through the office of the grand wazir for his confirmation. (Ibid: 7).

We see that the ta'ligheh of the grand wazir was considered as the Order of the second highest civil authority in the realm, it was considered very necessary as without his confirmation no Order could be issued, and usually the phrases of hasbul amar 'ala were written on the Order.

\section{Text (Ragham)}

Ragham is an Arabic word, which simply means a written text, but in the technical sense it is an official document with the sign of validation. Actual specimens of the document show that during the Safavid period, ragham was a different kind of Order which was issued for various purposes, for instance, there was ragham-i-khal'at which was written for mushrif-i-ghiejija khaneh (master tailor) in the form of siyagh. The 
Order was written and the square seal with the names of Imams on its margins and written was affixed. It seems that the kinds of ragham was more common during the early Safavid period. While ragham-i-tuyul was another type of Order which was done after the Order was registered in dafater-i-khulud and a draft made out of it. Then, mustufiyan-i-ezam-i-diwan affixed the muhri-musavadeh-i-diwan-i-'ala on it. Ragham-i-mavajeb was another type of a sanad-i-daftari and as the salary was paid, the ragham was prepared with the seal of the grand wazir, and this was always registered in dafater, it should be mentioned that the head of each office was supposed to put his own word which has to be confirmed by the concerned official. For instance, lashkarnevis used to write ragham-i-tankhwah of the soldiers and this ragham was not only sealed with muhr-i-musavadeh which had the name of king written on it and had a circular form, but the muhr-i-angushtar (aftab-i-athar) was also affixed. This seal during the reign of Shah Tahmasp was square and during the reign of Shah Sulayman changed into altar form. (Mss: 6293)

There was another ragham which was prepared in the assembly of beheshta'in for outlaying areas and this carried the ta'ligheh of hukm-i-jahan mut'a shud which was written in black ink.

Some of the argham were usually issued by oral Order of the king which was called argham-i-belmushafeh which according to ta'ligheh of wazir-i-diwana' $a$ was expressed by the phrase of hasbul-amr-a' $a$ and in such cases the waghehnevis used to prepare the tughra in black ink. (Mirza Sami'a, 1987: 6, 15)

Minorsky mentions that ragham was a general terms for Orders which were either in written form of conveyed orally while argham intesab (appointment Orders) were sealed by muhr-mihr athar and some of them were issued by wazir-i-'azam. (Minorsky, 1955:270) He mentions two kinds of ragham, i.e. ragham-i-daftari and ragham-i-bayazi of which the former was used to be written according to the drafts while the latter was written directly by the oral Order of the king. (Ibid: 271) None of these argham were valid without confirmation of wazir-i-diwan-i-a' $a$. Here the word of ragham has been used as a synonym for the signature of validation. In fact, Mirza Sami ${ }^{`} a$ use the word ragham in a different sense implying the Order of the king or princes. (Mirza Sami'a, 1987: 45, 50)

Argham was a title for farmans which the king himself had directly Ordered to be issued. The royal Orders were communicated in two ways written on the margin of petitions or Ordered by the king orally, which was called ragham-i-belmushafeh had usually this was issued for important appointments of financial affairs.

In fact, argham-i-manaseb and its endorsement was supposed to be confirmed by wazir-i-'azam by affixing his seal and by putting muhr-i-mihr-i-athar of the king. (Mirza Sami'a, 1987: 5)

The same procedure was adopted for ragham-i-mulazemat wa khedmat. As long as ta'ligheh of wazir-i-'azam was not there and it's zemn was not affixed with the seal of the wazir, the muhr-i-mihr-i-athar was never affixed. (Ibid)

According to Dastur-ul-Muluk, Order of appointment of umara, beglerbegiyan, salatin-i-mamalek mahruseh, wuzara wa mustufiyan-i-diwan-i-'ala were drafted by the writers of argham and after the registration of these Orders in dafter, majlesnevis put his tughra in black ink and he also decided the title for each post (mansab) as per dastur-ul-'amal, and then present his final recommendation to the king.(Miraz Rafi' $a, 1968: 92$ )

The person who prepared ragham was called raghamnevis, he was under the charge of waghehnevis of majlisnevis, there were eight raghamnevis who had different salaries and In'am but raghamnevis-i-diwan 'ala had 30 tuman as his mawajeb and they were entitled from the post holders, 40 dinars as their rusum. (Ibid: 298,543)

\section{Insignia (Nishan)}

During the Safavid period, munshi-ul-mamalek was responsible for preparing the musavadeh of nishan which went before the king and after being approved by namehnevisan who were working under munshi-ul-mamalek used to write the Order in nast'aligh character on the paper which they used to get from kutubkhaneh and muhazeban(illuminators) and depending on the dignity of the king of whom the said nishan was to be dispatched, they gild the paper with afshan tala and then the writer would write the matter. (Mirza Rafi'a, 1969:314)

Another point which one could make out from the study of these nishans is that usually nishan was issued according to the earlier Order that was issued during the former king as Safavid documents show on the top of the right side.

Phrases such as Shah Tahmasp nurallah marghadahu, jade buzurgwaram tabthara, shah-i-babam anarallah burhanahu and khaghan-i-janat makan 'iliyn ashyan has been noticed which shows that according to the earlier Orders these nishans were issued for the reconfirmation of the earlier Order.

Shatranji tughras were usually used for the nishans. Drawing the shatranji, tughra with 12 houses on the top of 
the seal in tughrai character, with each house bearing the name of one of the Imams and mentioning the name of the king alone with the word siuzmiz (in Turkish means our word) were the main features of the nishan.

Maghami writes that nishan was written for confirmation of argham and ahkam and contains the Order of the former nishan and it was different from parwanjat. Parwanjat was used to confirm the argham which had financial implication while nishans were to confirm argham and ahkam which were issued for suyurghal, tuyulat, manaseb and small posts. (Ghaem Maghami, 1970:82)

Among the Safavid documents, nishan was the only royal Order of which the first two or three lines were short and usually at the end, on the margin murh-i-khatam along with the king's own handwriting the word khtam was written to put an end to the nishan. (Mss: 6293)

It seems that by putting the phrase of farman humayun shud for the nishan, the first two lines and the word of khtam was abolished. (Ghaem Maghami, 1970:82)

It seems nishan was used to be written at diwan-i-'ala and was simply used for suyurghal, tuyulat and manaseb. Nishan was validated by two seals of muhr-i-sharaf-i-nafaz and muhr-i-humayun on its back and on the margin of the text and after ending the text, the king by his own handwriting puts the word khatam and was affixed with the seal of khatam.

Nishan's sarnameh was huwa alah subhan al mulkulala besmellah-i-rahman-i-rahim ya Muhammad ya 'Ali which were written in different lines following each other. (Mss: 6293)(fig.4)

\section{Appointment Orders}

Appointment Order was called Parwancheh. It was issued in accordance with the royal Orders or hukmnameh. Hukm-i-parwancheh belongs to the asnad-i-diwani which were issued for the actual appointment Orders, grants and permissions etc.

These Orders were issued to the subordinate officials in the manner of takid to perform in accordance with the earlier royal Order. The parwanjat were written by mustufiyan who submitted the draft to mustufi-ul-mamalek who used to appropriate the draft. (Mirza rafi'a, 1969:316)

Parwanjat after being registered at the dafater and tughra of munshi-ul-mamalek was placed; only then muhrdar would affix the seal at the first line of unwan-i-zemn in front of muhr-i-humayun. (Ibid: 311) In case of Parwanjat of manaseb, saheb toujeh-i-diwan-i-a'a would sign and affix the seal on the Order, (Mirza Sami'a, 1987:42) and in case of Parwanjat hamesleh, tuyul hesabi, after being approved by the wazir-i-diwan-i-a' $a$ and mustufi-ul-mamalek, it would go to awarejeh nevisan who would prepare the unwan of the Order, prepare a draft with the phrase of mulahezeh shud, or thabt namayand and put their signature under the phrases and then it would be registered at the sanad-i-daftariyan. (Ibid: 43, 44)

It seems all the parwanjat had to be approved and registered by the awarejeh nevisan by putting his khat (signature) and name of the zimn of parwanjat and also keep a copy of it in dafater as a proof. (Mirza Rafi'a, 1969:542)

There is another type of parwaneh which was known as parwaneh-i-eltezami and although it was issued by diwan begi, it was prepared by munshi-diwan who worked under munshi-ul-mamalek, (Ibid: 544) and in the last stage after munshi-ul-mamalek's tughra was placed on it, the Order went to the king for his consent.

Depending on the nature of these parwanjat whether it was a parwanecheh-i-hesabi, tankhawah, tuyul, hamesaleh, manseb, dad wa sited or eltezami,(Ibid: 542, 544) different authorities used to put their signature, and affix their seals granting the approval for it.

It seems that on the parwanjat related to dad wa sitad and drafts, tughra of farman-i-humayun shud was drawn on them along with invocation (unwan) of almalekulalla, and for the parwanjat of tuyulat-i-umara and manaseb-i-'ala tughra of sharaf-i-nafaz yaft was used. (Mss.6293)

Study of Safavid documents show that a majority of parwanjat were affixed with the seal muhr-i-mihr-i-athar and this phrase was also written at the end of the parwancheh i.e. chun parwanecheh be muhr-i-mihr-i-athar ashraf rasid i 'timad namayand or chun parwancheh be tuh'e wagh'e, ashraf rasid i'timad namayand or chun parwancheh be tugh'e wagh'e refe' mane' a shraf. Muzayan wa muhali gardad i' itemad namayand wa dar uhdhi shinasand (Puridzo, 1962:4, 5) and the invocation used on such parwancheh was huwa al mulkuallah (Ibid) with the tughra of farman humayun shud. (Ibid).

On the zemn of parwaneh seal of i'temad-ul-duleh, mustufi-ul-mamalek, nazer-diwan 'ala, darugheh were not depending upon the nature of the parwanjat, the officials concerned used to put their seal and signature on the 
zimn along with the phrases such as thabt shud, marghum shud, mulahezeh shud, be nazar rasid beghalam amad etc. (Ibid)(fig.5)

\section{Order on Religious Appointments}

Dehkhuda gives a literal meaning for methal but in the technical sense, it means farman or hukm and methal dadan means to give Order, and to keep someone's methal means "to keep his Order". Amthaleh belong to the category of asnad-i-diwani of Safavid period which was very common and was related to the mughufat and astaneha (endowed property for the benefit of holy shrines), and usually for appointment to these places, manaseb-i-astaneh and mughufat affairs under diwan-i-sedarat, methal and khetabeh used to be issued. (Tabatabai, 1974:7) Regarding methal, Maghami writes that these were written Orders and hukm-i-diwan-i-sedarat and dafter-i-mughfat were related to judicial officers and theses officers looking after the endowed properties were called methal. (Ghaem Maghami, 1970:54)

During the Safavid period, mughufat (endowments) were looked after by a separate ministry and it was divide into two department, khaseh and mamalik and this diwan had its own officials like mustufi, mutassadi, mutawlli and these asnad were to be registered in dafater-i-mughufat and the mustufi put his khat (signatures) on the asnad and issued them as amtheleh-i-daftari which were drafted in dafater-i-mughufat by methalnevisan. (Mirza Sami`a, 1987:44)

In some methals of mathenadaran these features are noticeable on the documents, two invocations of almulkuallah (Papaziyan, 1968:25,26), and huwa mulkuallah (Ibid: 41,42) were used as unwan and with tughra of farman-i-humayun shud, (Ibid) and after the tughra this phrase was repeated in all the methals, anke-be-mujebi ki methal lazemul-emtethal-i-diwan-i-sedarat al'liyhal 'aliyh dar zemn sader gashteh 'amal namayand. (Ibid) According to this phrase, methal of diwan-i-sedarat used to write in the zemn of the Order with an emphasis for the cooperation from the wukala, bigler begi and hukam of each place, to execute the Order.

In the zemn, of Order, above the tughra of sadr this phrase was written huwallah wal usweh and then tughra of the sadr which usually contain their names, two lines are short and the sadr put his seal at the end of the Order. (Ibid)

Regarding the main features of methal, Tabatabai says that, "methals are not only related to ahkam-i-sudur but dar ul ghaza and ghazi "askar also used to issue methal." In most of the methal, we notice that ane side hukm-i-sudur was written while on the other, the royal farman was written. The phrase of thabt-i-muhr-i-humayun-shud which was written on the back of the document along with the phrase thabt-i-dafater-i-mughufat shud, invariably were put on the methal. (Tabatabai, 1974:32)(fig.6)

\section{Draft}

During the Safavid period, barat (draft) was considered as sanad-i-mali-wa-mulki and according to it, the salary of civil officials was paid. According to Minorsky, sudur-i-barat used to issue a draft for receiving certain amount from the revenue of the government. (Minorsky, 1955:47) There were three kinds of barat: (i) yeksaleh for one year, (ii) hamesaleh for every year, the value of which latter was more and permanent as compared to the former one, and (iii) barat-i-jensi where instead of cash, some goods were fixed as salary. (Ibid: 163).

For the salary which was paid through the barat, Orders issued from any department had to be affixed with the seal and signature of the head of the department. In fact, tankhwah-i-barat or mawajeb barat (Ibid) was issued by the concerned department with the approval of the head but finally it had to be approved by the wazir-i-diwan 'ala only then, such drafts were paid. (Ibid: 8,9) Chardin says that these drafts were of two kinds: land draft and draft of royal account. While land drafts were known as tuyul. (Chardin, 1970:294)

In the latter category the income of the land was paid as salary of civil officials. It seems that barat-i-yeksaleh, which had different malek (owner) every year used to pay the amount, but barat-i-hamesaleh was permanent and always one person was in charge of such barat. (Ibid: 298) Usually, nazeran-i-iyalat-i-hamesaleh used to send the statement of income of the iyalat along with the list of income of each village and area which had been made by the local chiefs with their seal and signature, to the diwan-i-muhasebat, with one copy of it kept with the nazer and according to these statement they issued a receipt. Anyone having the said receipt could get his salary paid. (Ibid: 299)

Since all this matter is related to financial affairs, it used to pass from the office of nazer-i-daftar khaneh-i-humayun'ala. ( Mirza Sami‘a. 1987: 36) These barat-i-tuyul, tankhwah wa mawajeb passed through mustufi of each department who was accountable to daftarkhaneh-i-humayun. (Ibid: 38, 39) 


\section{Conclusion}

The study of a number of Safavid documents has helped us shed light on these documents in Order to categorize them and introduce them in the bureaucratic system or chancellery of the Safavid dynasty.

One reason that it took a long time for the Safavid chancellery to prepare a letter was to prevent any fabrication of the letters. Hence at times it took between four to six months for the chancellery to issue a letter. Another conclusion of the present paper is that many terminologies were borrowed from the Timurids and Turkmans. But despite the similarities in the terminologies, the procedures of the Safavid were much more complicated than those of the Timurid and Turkman. Another conclusion is that in the Safavid dynasty, although the king was the highest authority, the officials of the chancellery also enjoyed a relatively high influence.

Also another conclusion is that the performance of state affairs was not possible without an elaborate administrative set up. Therefore state affairs were divided among the ministers, who had a subordinate position to the king.

The Safavid administration was in the hands of seven ministers. The grand wizir was like the prime minister, and was considered as the second highest authority of the realm. It is also clear from the documents studied that diwan-i-insha was a center of epistolary as an important part of the Safavid administration.

Munsi-ul-mamalek, muhrdaran, dawatdaran and daftardaran were the important officials looking after the chancellery.

Diwan-i-istifa was in charge of translation of the entire country and Orders related to financial matters were under this diwan. Diwan ghaza was considered as the highest position in all the judicial and canonical affairs. The affairs of the Safavid court were in the hands of four amirs who were known as umara-i-dowlat khaneh like ghurchi bashi, ghullar aghasi, ishik aghasi and tufangchi bashi.

The said administrative system underlines the fact that the Safavid kingdom enjoyed a complicated bureaucratic system or chancellery, which helped them maintain a technical flow of work throughout the system which was in a sense the first nation-state in the Iranian history. It also helped the system prevent any fabrication of the royal letters and documents, which was necessary for the protection of the state security.

\section{References}

Order of Shah Abbas II to Mirza Nezamuddin Ahmad.(No:11002/4)

Order of Shah Abbas II to Hakem of Fars (No: 12002/39)

Order of Shah sulayman to bigler begi Mirza Hedayatalla (No: 13002/5)

Order of Shah Sultan Husain to Mirza Muhammad Taghi as Kalantar of Yazd (No: 13001/60)

Order of Shah Sultan Husain to Hakem of Fars (No: 13001/62)

Order of Shah Sultan Hasain to Mustufi Khaseh Lahijan (No: 13003/68)

Order of Shah Tahmasp I to Khan Ahmad beyk Safawi(No: 1220)

Order of Shah Sulayman to Mutawali tomb of Shaikh Safiuddin Ardabili( No: 1226)

Order of Shah Sultan Husain to biglerbegi of Ardabil.(No: 1222)

Order of Shah Tahmasp II to Murteza gholi beyk Safawi.(No: 1223)

Feraydun Beyk (982AH/1574 AD), Munshet ul Salatin, No.200242, National library,Tehran.

Heydar Beyk Ivaghli (ca1042 AH/1633 AD), Majmaul Insha, Mss.No:3558(Microfilm) Tehran university lib.

Anonymous. Dasturul 'Amal, Mss. 13787-6293, Malek lib. Tehran.

H.Papaziyan, Ghabaljat-i-Farsi, Academic Science, Iravan, 1959.

Faramin Farsi Matinadaran, 2vols, Academic Science, Iravan, 1968-1969.

V.puturidzo, Asnad Farsi Gurjestan, Academic Science Gurjistan, 2vols, 1961-1962.

J.Ghaem Maghami, Yik Sadu panjah Sand Tarikh az Jalayer ta Pahlavi, Tehran, 1970.

Z.Thabetiyan, Asnad wa Mukatebat Tarikhi wa Ijtema'e, Ibn Sina, Tehran,1964.

A.A.Dehkhuda, Lughatnameh Dehkhuda, Tehran university, 1945-1971.

H.Busse. Razhuhishidar Tashkilat Diwan Islami tr.B.Varahram, M.T.F. Tehran, 1988.

J.Ghaem Maghami, Mughadamehe bar Asnade Tarikhi, Anjuman Athar Melli, Tehran, 1970. 
J.Chardin, Account of Chardin, tr.M.Abbasi, (2, 4, 8, 9.vols), Amir Kabir, Tehran, 1966, 1969, 1970.

Mirza Sami‘a, Tazkerat ul muluk, edited, M.Dabir Siyaghi, Amirkabir, Tehran, 1987.

Mirza Rafi‘a, "Dastur ul Muluk", edited, M.T.Daneshpazhuh, Majaleh Daneshkadeh Adabiyat, Tehran university, $15^{\text {th }}, 16^{\text {th }}$, year $1968-1969$.

M.Tabatabai, Methalhayeh Sudur Safawi, Hekmat, Ghum, 1974.

V.Mirnorsky, Sazeman Idari Hukumat Safawi, edited, M.Dabir Siyaghi, tr.M.Rajabnia,Zuzar, Tehran, 1955.

\section{Copyrights}

Copyright for this article is retained by the author(s), with first publication rights granted to the journal.

This is an open-access article distributed under the terms and conditions of the Creative Commons Attribution license (http://creativecommons.org/licenses/by/3.0/). 